\title{
Speed Adjustment on Variable Frequency Induction Motor Using PLC for Automatic Polishing Machine
}

\author{
Agung Prasetyo Utomo ${ }^{1}$, Anggara Trisna Nugraha ${ }^{2}$, Naufal Praska Zakariz ${ }^{2}$, Lailia Nur Safitri², Adam Meredita \\ Realdo $^{2}$, Fahmi Ivannuri², Alwy Muhammad Ravi², Dadang Priyambodo ${ }^{2}$ \\ ${ }^{1}$ Ship Design and Construction Engineering, Shipbuilding Institute of Polytechnic Surabaya, Surabaya ${ }^{1}$ \\ ${ }^{2}$ Marine Electrical Engineering, Shipbuilding Institute of Polytechnic Surabaya, Surabaya ${ }^{2}$ \\ Jl. Teknik Kimia Keputih Sukolilo, Surabaya 60111, Indonesia
}

\section{Article Info \\ Article History: \\ Received: April 5, 2021 \\ Revision: April 15,2021 \\ Accepted: May 28, 2021}

\section{Keywords: \\ Speed Control \\ Inverters}

Modification
This work is an open-access article and licensed under a Creative Commons Attribution-ShareAlike 4.0 International License (CC BY-SA 4.0).

$$
\text { License ( } \underline{\text { CC BY-SA 4.0 }} \text {. }
$$

\author{
Corresponding Author: \\ Anggara Trisna Nugraha \\ anggaranugraha@ppns.ac.id, \\ Marine Electrical Engineering \\ Shipbuilding Institute of Polytechnic Surabaya \\ Jl. Teknik Kimia Keputih Sukolilo, Surabaya 60111, Indonesia
}

\section{INTRODUCTION}

To produce ceramics, companies must carry out a production process that is closely related to hard materials (such as stone). To produce a perfect ceramic process, absolutely reliable electrical and mechanical equipment is needed [1]. Atmam's research in 2018 was carried out by adding a VSD which aims to overcome these problems which require a way to maintain electrical energy. One way to protect the use of electrical energy in a three-phase induction motor is to use a Variable Speed Drive (VSD), but this study does not apply to the VSD in detail and the motor used in this study is a 3-phase motor. Furthermore, Muhammad Otong's research in 2016 was carried out by adding VSD to an electric car drive system using the unipolar sinusoidal pulse width modulation (SPWM) switching modulation technique. In Siti Nur Alima's research in 2020, it was carried out using a load, namely a single-phase induction motor, but the difference is in the VSD system used by metoe PI in the control system. In a study conducted by Endro Wahjono in 2015, a study on VSD was carried out, but the method used was fuzzy logic based on direct torque control using a car motor load. In this industry, many propulsion machines are used, namely electric motors used in production machines [2]. The production unit is part of the whole production process, during this process the stone polishing machine unit is operated manually, starting from polishing with a manual grinder, so the effect will not be maximized [3]. Therefore, it is necessary to modify the system by designing an automatic polishing machine that uses a PLCbased converter [4]. Hopefully the automatic machine design can provide better and maximum results [5].

In the last century, DC motors have run on a constant voltage power supply (BUS) [6]. The speed can be changed simply by changing the magnetic flux of the motor. Here, we face a serious problem, in this arrangement, there is a spark on the commutator, which limits the life of the brush and commutator [7]. Then in 1890, the development of the Ward-Leonard system was very meaningful for the evaluation of DC motor drives, which use generators and electric motors to drive DC motor drives. In the 1940 s, all systems primarily used air conditioning to further develop the ward system - Leonard used an AC motor [8]. This system can increase ceramic output and improve quality. In this case, assuming that the operator usually uses an automatic 
system to complete the work of the three operators, the polishing machine production costs can be reduced. In this industry, a lot of propulsion machines are used for production machines, namely electric motors. One of the production units which is part of the entire production process of PT. ROFENTI KARSA TAMA is a stone polishing machine unit. So far, the operation is still done manually, starting from polishing using a humanoperated hand grinder, so the results are not optimal. Therefore, the study aims to modify a system by designing an automatic polishing machine using a PLC-based converter. From the automatic machine design, it is hoped that it can provide better and maximum results.

\section{MATERIALS AND METHODS}

\section{A. Material}

\section{1) Induction Motor}

Three phase induction motors are usually widely used in factories. Motors with a capacity of $200 \mathrm{KW}$ are usually designed for low voltages [9], while motors with a capacity of $200 \mathrm{KW}$ and above are usually designed for medium voltages. This is because the bigger the motor, the greater the current, which means you have to use a larger cable as the coil, and it is difficult to bend and shape with this large cable [10]. Therefore, to solve this problem, you need to increase the voltage that the motor should use [11]. The speed of an induction motor is influenced by the number of poles on the stator and the frequency of the voltage source. It is calculated as follows (1) [12]:

$$
n_{s}=\frac{120 x f}{p}
$$

where $\mathrm{n}_{\mathrm{s}}$ indicates synchronous speed, f indicates frequency, and $\mathrm{p}$ indicates number of poles. The difference between synchronous speed and rotor speed is called slip (s), expressed (2) $[13]$ :

$$
s=\frac{n_{s}-n}{n_{s}}
$$

where $\mathrm{s}$ indicates slip, $\mathrm{n}_{\mathrm{s}}$ indicates synchronous speed (rev per $\min )$, and $\mathrm{n}$ indicates the rotor speed.

Engine speed (M-1) is $5 \mathrm{~Hz} ; 11 \mathrm{KW}$ function, used to adjust the polishing net before and after the polishing tank, M-2 $10 \mathrm{~Hz}$; $5.5 \mathrm{KW}$ function can set clean left and right polishing, the M-3 motor is $0-50 \mathrm{~Hz} ; 7.5 \mathrm{KW}$, adjust the speed according to the type of stone.

\section{2) Use of Inverters in Induction Motors}

Induction motors are one of the most widely used equipment in industry, used to drive a variety of industrial processes, including: pumps, compressors, entertainment equipment, blowers, conveyors and other production process drivers [15]. This is because induction motors have many advantages over synchronous motors or DC motors, namely, they are simple in structure, durable, easy to maintain, and very efficient [16]. There are drawbacks behind these advantages, namely in terms of speed settings and low starting torque [17]. To solve this problem, a control system can be used by adjusting the input voltage and frequency to obtain speed and torque settings that meet the requirements of the industrial production process [18] (Fig. 1).

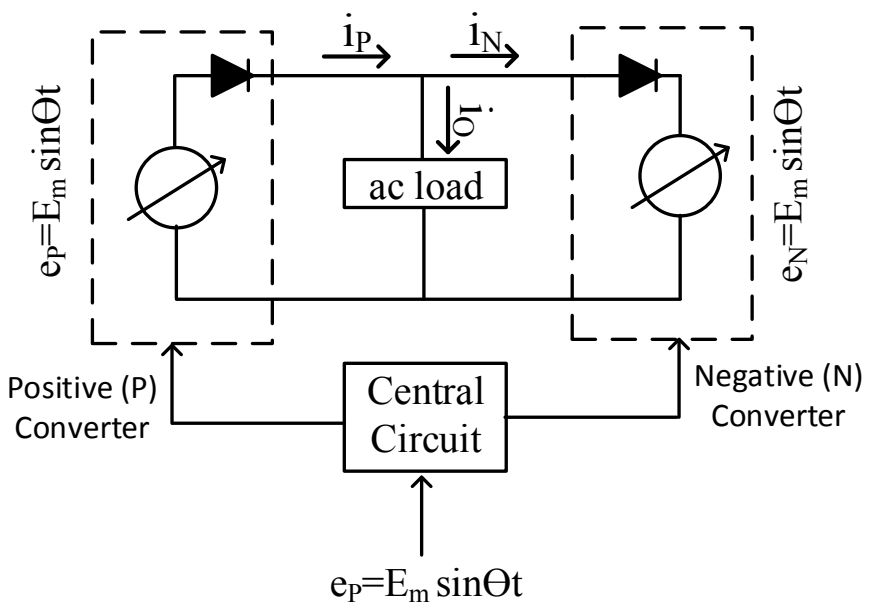

Fig 1. Basic Principle of Converter [14]

\section{3) Introduction to PLC and Ladder Diagrams}

A programmable logic controller (PLC) is basically a computer specially designed to control a process or machine. Process control can be continuous variable adjustment, such as in a servo system, or it can involve only two state controls (on / off), but requires repetitive operation, which is common in drilling machines, conveyor systems, etc.

\section{B. Method}

By obtaining actual motor load data from the multimeter or directly from the inverter, since the inverter itself can display the load controlled by the inverter, there is no need to use the multimeter directly for measurements, and the results are more realistic.

\section{Calculation Analysis}

The data above is the process data used for design. To get the actual process data, the sequence of calculations is as follows:

After knowing the average speed, calculate the drive motor power $(\mathrm{KW})$ as measured by the load analyzer [13]. This KW is multiplied by the efficiency of the motor transmitting shaft / shaft power to the fan, expressed as (3):

$$
P=\sqrt{3} x V x I x \cos \varphi
$$

where $\mathrm{P}$ indicates power $(\mathrm{W}), \mathrm{V}$ indicates voltage $(\mathrm{V}), \mathrm{I}$ indicates current (A), and $\cos \varphi$ indicates power factor. Calculating the rotational speed of the motor and stator with the equation (4):

\section{Accredited by Ministry of Research and Technology /National Research and Innovation Agency Decree No: 200/M/KPT/2020}




$$
n_{s}=\frac{120 x f}{p}
$$

where $n_{s}$ indicates stators rotation $(\mathrm{m} / \mathrm{s}), \mathrm{n}_{\mathrm{r}}$ indicates rotor rotation $(\mathrm{m} / \mathrm{s}), \mathrm{p}$ indicates number of poles, and $\mathrm{f}$ indicates frequency $(\mathrm{Hz})$. Comparison of efficiency using a variable speed drive and manual. Efficiency can be expressed as follows (5):

$$
n_{i}=\frac{P_{\text {out }}}{P_{\text {in }}} \times 100 \%
$$

where $\mathrm{n}_{\mathrm{i}}$ indicates efficiency $(\%), \mathrm{P}_{\text {out }}$ indicates output power (Watt), and $\mathrm{P}_{\text {in }}$ indicates power (Watt).

\section{RESULTS}

\section{A. Production Calculation Analysis}

\section{1) Manual Machine Calculation}

When using a manual system for production calculation, in one hour of production, if in one working day there are 400 operators and the equipment is valid, each operator can produce 50 parts. The cost per piece is Rp. 100, the system daily production costs. The manual price is Rp per day. 40,000. If the yield after cutting is 400 or higher, but if the stone after cutting is not good, the output will drop from 400 (Table I).

TABLE I. MANUAL SYSTEM

\begin{tabular}{cccc}
\hline No & Production Hours & Qty (Pcs) & Production cost (Rp) \\
\hline 1 & 1 Hour & 50 Pcs & Rp. $100 /$ Pcs \\
\hline 2 & 8 Hour & 400 Pcs & Rp. 40.000 \\
\hline
\end{tabular}

\section{2) Automatic Machine Calculation}

In the 10-minute production calculation, if the automatic equipment produces 1,536 units in one working day ( 8 hours), the automatic equipment will produce 32 sets, and the automatic equipment will produce 192 sets within 1 hour. In the case of a manual system, the operator can only get 400 computers per day, which takes 8 hours of work. This means that in a day, the factory can save 3 operators in production costs.

TABLE II. AUTOMATIC SYSTEMS

\begin{tabular}{cccc}
\hline No & Production Hours & Qty (Pcs) & Production cost (Rp) \\
\hline 1 & 10 Minute & 32 Pcs & - \\
\hline 2 & 1 Hour & 192 Pcs & - \\
\hline 3 & 8 Hour & 1536 Pcs & Rp 48.000 \\
\hline
\end{tabular}

B. Study of Variable Speed Drive Usage on Induction Motor

To use the variable speed drive application that will be used in the variable speed torque variable speed application, because the induction motor is connected to mechanical equipment in the form of a fan belt. The tendency to overload can cause slippage between the induction motor pulley and the main pulley, so that the application used in this automatic system is variable torque (Table II).

According to the model, the VFD operating parameters can be programmed in the following ways: special programming software, internal keyboard, external keyboard, or SD card. MCC normally prevents most programming changes at runtime. General parameters that need to be adjusted include: motor nameplate information, speed reference source, start / stop control source, and brake control. MCC usually provides debugging information, such as error codes and input signal status.

Most MCCs allow automatic startup activation. After restarting, once the problem is resolved or the emergency stop signal is restored (usually the emergency stop is a low-level active logic), it will push the output to the specified frequency. A popular method of controlling the VFD is to activate automatic start and place L1, L2 and L3 on the contactor. Therefore, turning on the power contactor will start the driver and make the output of the driver reach the specified speed. Therefore, turning on the contactor power starts the drive and causes the drive output to reach the specified speed. According to the complexity of the drive, various automatic start-up behaviors can be developed. For example, a drive will automatically start at start-up, but will not automatically start from an emergency stop prior to the erase cycle.

\section{Experiment on Using Variable Speed Drive}

According to the above calculation data, the power consumption requirement of the automatic polishing machine is around $15 \mathrm{KW}$. To find out how much energy is saved, an experiment was carried out using a $15 \mathrm{KW}$ motor (Table III).

TABLE III. DATA FROM INVERTER TRIAL ON AUTOMATIC

\begin{tabular}{|c|c|c|c|c|c|}
\hline \multirow[b]{2}{*}{ No } & \multicolumn{5}{|c|}{ Manual } \\
\hline & $\begin{array}{c}\text { Kinds of } \\
\text { Stone }\end{array}$ & $\begin{array}{l}\text { Speed } \\
(\mathrm{Rpm})\end{array}$ & $\begin{array}{c}\text { Frequency } \\
(\mathrm{Hz})\end{array}$ & $\begin{array}{l}\text { Current } \\
\text { (A) }\end{array}$ & $\begin{array}{c}\text { Power } \\
(\mathrm{Kw})\end{array}$ \\
\hline 1 & $\mathrm{TCH}$ & 2000Rpm & $50 \mathrm{~Hz}$ & $2,55 \mathrm{~A}$ & $0,56 \mathrm{Kw}$ \\
\hline 2 & ONIX & 2000Rpm & $50 \mathrm{~Hz}$ & $2,55 \mathrm{~A}$ & $0,56 \mathrm{Kw}$ \\
\hline 3 & TAN & 2000Rpm & $50 \mathrm{~Hz}$ & $2,55 \mathrm{~A}$ & $0,56 \mathrm{Kw}$ \\
\hline 4 & KP & 2000Rpm & $50 \mathrm{~Hz}$ & $2,55 \mathrm{~A}$ & $0,56 \mathrm{Kw}$ \\
\hline 5 & ALOR & 2000Rpm & $50 \mathrm{~Hz}$ & $2,55 \mathrm{~A}$ & $0,56 \mathrm{Kw}$ \\
\hline 6 & CERRIE & 2000Rpm & $50 \mathrm{~Hz}$ & $2,55 \mathrm{~A}$ & $0,56 \mathrm{Kw}$ \\
\hline \multirow[b]{2}{*}{ No } & \multicolumn{5}{|c|}{ Automatic } \\
\hline & $\begin{array}{c}\text { Kinds of } \\
\text { Stone }\end{array}$ & $\begin{array}{l}\text { Speed } \\
(\mathrm{Rpm})\end{array}$ & $\begin{array}{c}\text { Frequency } \\
(\mathrm{Hz})\end{array}$ & $\begin{array}{l}\text { Current } \\
\text { (A) }\end{array}$ & $\begin{array}{c}\text { Power } \\
(\mathrm{Kw})\end{array}$ \\
\hline 1 & $\mathrm{TCH}$ & 1920Rpm & $35 \mathrm{~Hz}$ & $11,23 \mathrm{~A}$ & $5,45 \mathrm{Kw}$ \\
\hline 2 & ONIX & 2400Rpm & $40 \mathrm{~Hz}$ & $11,23 \mathrm{~A}$ & $5,45 \mathrm{Kw}$ \\
\hline 3 & TAN & 2400Rpm & $40 \mathrm{~Hz}$ & $11,23 \mathrm{~A}$ & $5,45 \mathrm{Kw}$ \\
\hline 4 & $\mathrm{KP}$ & 2400Rpm & $40 \mathrm{~Hz}$ & $11,23 \mathrm{~A}$ & $5,45 \mathrm{Kw}$ \\
\hline 5 & ALOR & 1500Rpm & $25 \mathrm{~Hz}$ & $11,23 \mathrm{~A}$ & $5,45 \mathrm{Kw}$ \\
\hline 6 & CERRIE & 1800Rpm & $30 \mathrm{~Hz}$ & $11,23 \mathrm{~A}$ & $5,45 \mathrm{Kw}$ \\
\hline
\end{tabular}
POLISHING MACHINE

\section{Accredited by Ministry of Research and Technology /National Research and Innovation Agency Decree No: 200/M/KPT/2020}




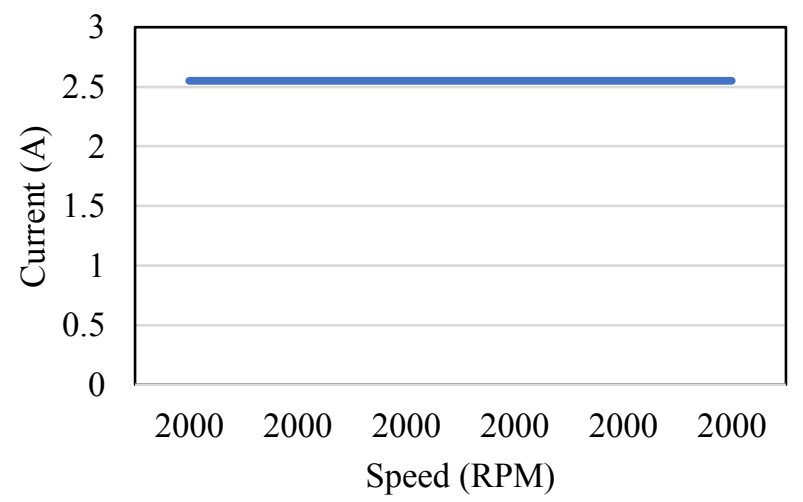

Fig 2. Graph of rpm and current by type of stone on a manual polishing machine

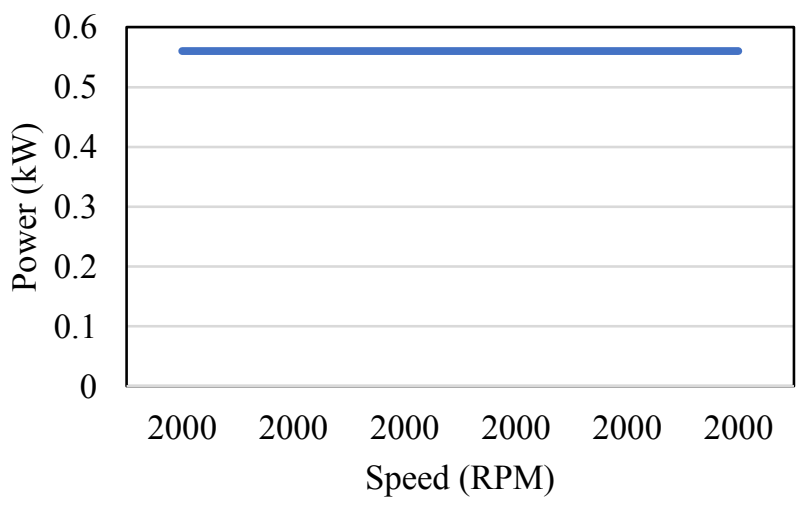

Fig 3 Graph of rpm against power by type of stone on a manual polishing machine

As shown in the Fig 2 and Fig. 3, the manual polishing machine will provide constant speed (rpm), current (A) and power (KW), even under different masonry conditions, the working effect is also the best. Maximizing continuous machine operation will shorten machine life or require more routine machine inspections.

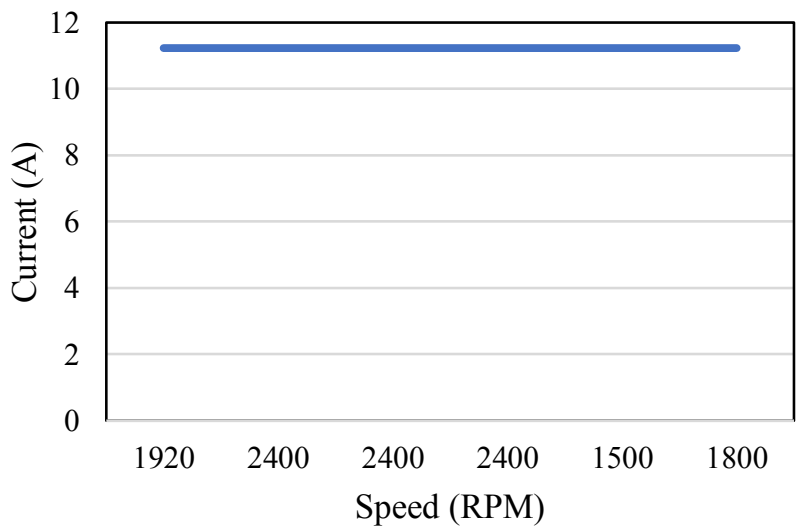

Fig 4. Graph of rpm against current by type of stone on an automatic polishing machine

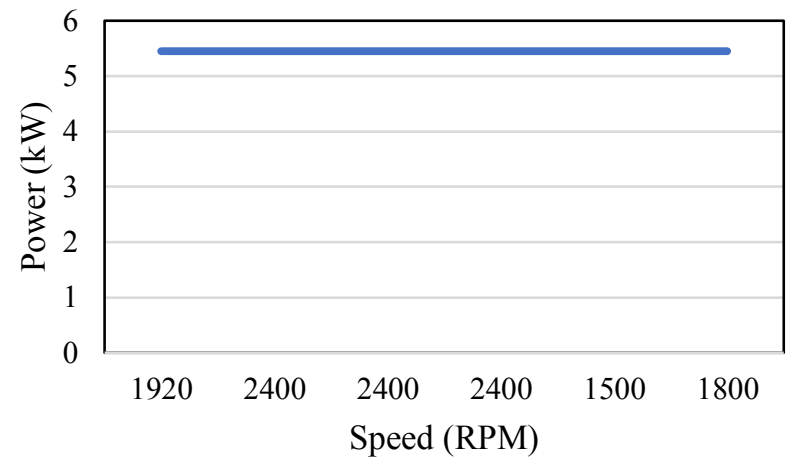

Fig 5. Graph of rpm against power by type of stone on an automatic polishing machine

The Fig. 4 and Fig. 5 shows that an automatic polishing machine will produce different speed (rpm), current $(\mathrm{A})$ and power $(\mathrm{KW})$ according to different gem types. The speed of the motor will be adjusted according to various types of stones in order for the machine to achieve the best working conditions. The power generated by an automatic polishing machine is very large, so the polishing machine is more efficient and can save production time.

\section{Analysis of Cost Savings for Polishing Operators}

Before deciding to replace the automatic polishing drive system with variable speed drive, it is best to find out how much efficiency the operator can save by using variable speed drive. To simplify the calculation, the following assumptions are required:

1. power factor $=0.96$ (using a capacitor bank)

2. Voltage $=380 \mathrm{VAC}$

3. Operating time of 300 days in 1 year

4. Energy price $=$ IDR $880 \mathrm{KWH}$

5. This calculation is based on the automatic M-1 machine

To calculate the efficiency of automatic polishing, the same calculation as above can be used (Table IV).

TABLE IV. COST SAVINGS WHEN USING VARIABLE SPEED DRIVE ON AUTOMATIC POLISHING MACHINES

\begin{tabular}{|c|c|c|c|c|}
\hline \multirow[b]{2}{*}{ Sistem } & \multicolumn{4}{|c|}{ Before } \\
\hline & $\begin{array}{l}\text { Qty } \\
\text { (Pcs) }\end{array}$ & $\begin{array}{l}\text { Day } \\
\text { (Rp) }\end{array}$ & Month (Rp) & Year (Rp) \\
\hline \multirow{2}{*}{ Manual } & 480 & Rp. & $\mathrm{Rp}$ & Rp. \\
\hline & Pcs & 40.000 & 1.200 .000 & 14.400 .000 \\
\hline \multirow[b]{2}{*}{ System } & \multicolumn{4}{|c|}{ After } \\
\hline & $\begin{array}{l}\text { Qty } \\
\text { (Pcs) }\end{array}$ & $\begin{array}{l}\text { Day } \\
\text { (Rp) }\end{array}$ & Month (Rp) & Year (Rp) \\
\hline Automatic & $\begin{array}{l}1536 \\
\text { Pcs }\end{array}$ & $\begin{array}{c}\text { Rp. } \\
48.000\end{array}$ & $\begin{array}{c}\text { Rp. } \\
1.440 .000\end{array}$ & $\begin{array}{c}\text { Rp. } \\
17.280 .000\end{array}$ \\
\hline
\end{tabular}

The table above shows the difference between the costs before and after using the automatic polishing system. The manual polishing output achieved by the operator per day is \pm 400 pieces / day, and the daily production cost is IDR 40,000. Such

\section{Accredited by Ministry of Research and Technology /National Research and Innovation Agency


a month's income is Rp. 1,200,000, reaching Rp in one year. 14.4 million, -. For a system that uses a variable speed drive on this polishing machine, the system can produce \pm 1536 PCs for one operator per day, and a monthly production cost of Rp. 48,000 / day. 1,440,000, reaching Rp in one year. 17,280,000. Therefore, the costs saved in the current automation system could save Rp. 90,000 Rp per day. At 2,700.00 per month, the effect is even better. An operator can compare three operators in a manual system with three operators in an automatic system, and the results are shown in the table above.

The difference between manual and automatic systems using variable speed drives is yield and production quality. The investment cost for this project is around $\mathrm{Rp}$. 12 million meaningful calculation assumptions are as follows:

Financial Benefits:

- Total Monthly Savings = IDR 2,700,000

- Payback Time:

$$
\begin{aligned}
& =\frac{\text { Total Investment Costs }}{\text { Total Monthly Savings }} \\
& =\frac{12.000 .000}{2.700 .000} \\
& =4,4 \text { Month }
\end{aligned}
$$

Power Efficiency when Manual:

$$
\begin{aligned}
P_{\text {out }} & =V \times I \\
& =220 \times 3,5 \\
& =770 \mathrm{Watt} \\
n_{p} & =\frac{P_{\text {out }}}{P_{\text {in }}} \times 100 \% \\
& =\frac{770 \mathrm{w}}{570 \mathrm{w}} \times 100 \% \\
& =1,35 \%
\end{aligned}
$$

Power Efficiency when Using Variable Speed Drive:

$$
\begin{aligned}
P_{\text {out }} & =\sqrt{3 \times} \text { V } x \text { I } \times \cos \varphi \\
& =1,73 \times 380 \times 14,5 \times 0,96 \\
& =9151 \text { Watt } \\
n_{p} & =\frac{P_{\text {out }}}{P_{\text {in }}} \times 100 \% \\
& =\frac{9151 w}{5500 w} \times 100 \% \\
& =1,66 \%
\end{aligned}
$$

\section{Discussion}

This research discusses the improvement of the induction motor drive system which is usually controlled by the Cyclo Converter which is only suitable for high power drives and at lower speeds. For this reason, research was carried out on the VSD system using a PLC in a polishing machine.

From the research conducted, the manual polishing machine will provide constant speed (rpm), current (A) and power (KW), even under different masonry conditions, the working effect is also the best. Maximizing continuous machine operation will shorten machine life or require more routine machine inspections. And then the automatic polishing machine will produce different speed (rpm), current (A) and power (KW) according to different gem types. The speed of the motor will be adjusted according to various types of stones in order for the machine to achieve the best working conditions. The power generated by an automatic polishing machine is very large, so the polishing machine is more efficient and can save production time. In previous studies using manual systems for production calculations, in one hour of production, if in one working day there are 400 operators and the equipment is valid, each operator can produce 50 spare parts. Cost per piece of Rp. 100, daily production cost system. The manual price is Rp per day. 40,000 . If the yield after cutting is 400 or higher, but if the stone after cutting is not good, the output will drop from 400. This system can increase ceramic output and improve quality. In this case, assuming that the operator usually uses an automatic system to complete the work of the three operators, the polishing machine production costs can be reduced.

\section{CONCLUSION}

Through the calculation and data analysis of the variable speed drive installation data on an automatic polishing machine, the following conclusions can be drawn, among others and can increase ceramic output and improve quality. In this case, assuming that the operator usually uses an automatic system to complete the work of the three operators, the polishing machine production costs can be reduced.

Use the automatic polishing machine system. Compared to the manual system, the electric motor in this system has a higher power of $4.93 \mathrm{~kW}$ and an output power of 1056 Pcs. By using a variable speed drive, the production cost of the polishing machine can be saved to Rp. 2.7 million. For KP gemstones which tend to be soft and brittle, a speed of $2400 \mathrm{rpm}$ is required, while for ALLOR gemstones $1500 \mathrm{rpm} /$ minute, the TCH speed is $1920 \mathrm{rpm} /$ minute. The variable speed drive will be applied to the polishing machine, and the motor load on the polishing machine will change frequently, and the goal is that if the output changes, the motor speed will change easily. Select an economical brand and variable speed drive type. From the price comparison, I chose the 40011 OMRON MX M-1 because it was the cheapest. With this OMRON brand, the payback period for your investment is 4.4 years, and the total investment is IDR 12,000,000. In subsequent years, the wages in the continuous polishing department have remained unchanged.

\section{REFERENCES}

[1] Neermarga, Amogh Ananth, V. R. Chirag, and Denver Prajwal Martis. "Design and Fabrication of Automatic Shoe Polishing Machine." National Conference on Advances in Mechanical Engineering Science.

[2] Endro Wahjono, 2015. Induction Motor Speed Control As Electric Car Driver With Fuzzy Logic Controller Direct Torque Control Based. PENS.

[3] Namekawa, Masahiro, et al. "Development of Automatic Polishing System using Object Recognition: A Faster R-CNN Approach." (2019).

[4] Iwan Setiawan, (ISBN: ISBN 979-763-099-4, Andi Publisher Yogyakarta, 2006)

[5] Shneor, Yair. "Reconfigurable machine tool: CNC machine for milling, grinding and polishing." Procedia Manufacturing 21 (2018): 221-227.

\section{Accredited by Ministry of Research and Technology /National Research and Innovation Agency Decree No: 200/M/KPT/2020}

Journal homepage: http://ijeeemi.poltekkesdepkes-sby.ac.id/index.php/ijeeemi 
[6] Moch syaik, 2002 Analysis of the speed control system with a VVVF inverter and braking on the main drive motor of KRL produced by PT.Inka Madiun

[7] Nugraha, Anggara Trisna, and Dadang Priyambodo. "Analysis of Determining Target Accuracy of Rocket Launchers on Xbee-Pro based Wheeled Robots to Realize the Development of Technology on the Military Field." Journal of Electronics, Electromedical Engineering, and Medical Informatics 2.3 (2020): 114-118.

[8] Wu, Xiang, et al. "A novel force-controlled spherical polishing tool combined with self-rotation and co-rotation motion." IEEE Access 8 (2020): 108191-108200.

[9] Xie, Xiaoguang, et al. "Evaluation of polishing behavior of fine aggregates using an accelerated polishing machine with real tires." Journal of Transportation Engineering, Part B: Pavements 145.2 (2019): 04019015.

[10] Nugraha, Anggara Trisna, and Dadang Priyambodo. "Design of Pond Water Turbidity Monitoring System in Arduino-based Catfish Cultivation to Support Sustainable Development Goals 2030 No. 9 Industry, Innovation, and Infrastructure." Journal of Electronics, Electromedical Engineering, and Medical Informatics 2.3 (2020): 119-124.

[11] Wang, C. J., et al. "A novel multi-jet polishing process and tool for highefficiency polishing." International Journal of Machine Tools and Manufacture 115 (2017): 60-73.

[12] Nugraha, Anggara Trisna, and Dadang Priyambodo. "Design of a Monitoring System for Hydroganics based on Arduino Uno R3 to Realize Sustainable Development Goals number 2 Zero Hunger." Journal of Electronics, Electromedical Engineering, and Medical Informatics 3.1 (2021): 50-56.

[13] Kumar, Yerraguntla Shasi, and Gautam Poddar. "Medium-voltage vector control induction motor drive at zero frequency using modular multilevel converter." IEEE Transactions on Industrial Electronics 65.1 (2017): 125 132.

[14] Yang, Zebin, et al. "Adaptive exponential sliding mode control for a bearingless induction motor based on a disturbance observer." IEEE Access 6 (2018): 35425-35434.

[15] Kirschen, Daniel S., Donald W. Novotny, and Thomas A. Lipo. "On-line efficiency optimization of a variable frequency induction motor drive." IEEE transactions on industry applications 3 (1985): 610-616.

[16] Kastha, Debaprasad, and Bimal K. Bose. "Fault mode single-phase operation of a variable frequency induction motor drive and improvement of pulsating torque characteristics." IEEE Transactions on Industrial Electronics 41.4 (1994): 426-433.

[17] Umanand, Prof. L., 2007, Non-Conventional Energy Systems. Bangalore: Indian Institute of Science Bangalore.

[18] Tong, C.W., 1997, The Design And Testing Of A Wind Turbine For Malaysian Wind Condition, thesis, UTM.

[19] Pikatan, Sugata., 1999, Conversion of Wind Energy. Surabaya: Department of Mathematics and Natural Sciences, University of Surabaya 